\title{
PENERAPAN MODEL PEMBELAJARAN MATEMATIKA MELALUI PEMECAHAN MASALAH UNTUK MENINGKATKAN PENALARAN MATEMATIS SISWA KELAS X-A SMA AL-MUSLIMUN
}

\author{
Maimunah $^{1}$, Purwanto ${ }^{2}$, Cholis Sa'dijah ${ }^{3}$, Sisworo ${ }^{4}$ \\ ${ }^{1}$ Universitas Riau, Jl. Binawidya KM 12,5 Simpang Baru Pekanbaru Riau \\ ${ }^{2,3,4}$ Universitas Negeri Malang, Jl. Semarang 5 Malang
}

\begin{abstract}
The purpose of this study to improve students mathematical reasoning with the application of teaching mathematics through problem solving. This models consist of four fase, that is: giving problems, investigation, presentation results, and evaluation results. Method of research is quasi experimental is implemented in class X-A SMA Al Muslimun Pelalawan Riau. Subject of this study were 19 students who divided into groups of 4-5 students with the capability of high, medium, and low. The instrument used was a test and observation. In the pretest result there were 10 students with sufficient reasoning and good criteria. While on the posttest there were 19 students with the criterion of mathematical reasoning is good. No students obtains criterion of mathematical reasoning is very good in two test.
\end{abstract}

Keywords: Mathematical reasoning; Problem solving; Mathematics teaching

\section{PENDAHULUAN}

Matematika sebagai ilmu dasar memegang peranan penting dalam kehidupan manusia. Hal itu sesuai dengan pendapat Hudojo (2005) yang menyatakan bahwa matematika adalah suatu alat untuk mengembangkan cara berpikir, karena sangat diperlukan dalam kehidupan sehari-hari maupun dalam menghadapi kemajuan IPTEK. Oleh karena itu, matematika sebagai bagian dari kurikulum pendidikan dasar dan menengah, memainkan peranan strategis dalam peningkatan kualitas Sumber Daya Manusia (SDM).

Peningkatan kualitas SDM dapat dilakukan melalui pendidikan, khususnya pembelajaran di sekolah. Salah satu upaya yang dilakukan adalah adanya perubahan kurikulum, dari kurikulum 1994, KBK, KTSP, hingga K-13. Perubahan mendasar yang dilakukan adalah bagaimana guru mengajar dan bagaimana siswa belajar. Perubahan semacam ini menghendaki kesabaran guru dalam mengarahkan siswa sehingga mereka menjadi tahu, mampu dan mau belajar dan menerapkan apa yang sudah mereka pelajari di lingkungan sekolah maupun masyarakat sekitarnya. 
Hasil wawancara dengan beberapa guru matematika dan hasil pengamatan pelaksanaan pembelajaran di SMA Al Muslimun Pelalawan Riau, ditemukan bahwa sebagian besar guru matematika melakukan pembelajaran dengan langkah-langkah sebagai berikut: menjelaskan materi, memberi contoh-contoh soal, dan memberi latihanlatihan. Langkah tersebut menurut anggapan beberapa guru lebih mudah dan cepat karena materi yang disajikan dapat tercapai sesuai kurikulum. Hasil pengamatan terhadap aktivitas yang dilakukan siswa menunjukkan bahwa siswa kurang aktif pada saat pembelajaran berlangsung. Siswa juga belum terbiasa bertanya dengan baik dan masih belum dapat menganalisis dan memecahkan masalah melalui diskusi. Mereka cenderung menanti jawaban dan penjelasan dari guru dan tidak berkenan untuk mencari pemecahan masalahnya terlebih dahulu. Kegiatan pembelajaran seperti biasa hanya mendorong siswa untuk berpikir pada tataran rendah dan tidak mengakomodasi kemampuan kognitif tingkat tinggi siswa, dan kurang memberi hasil yang optimal. (Armanto, 2002; Rochmad, 2009).

Krulik, Rudnick, \& Milou (2003) menyatakan bahwa penalaran sangat diperlukan dalam pembelajaran matematika dan sebagai bagian dari berpikir tingkat tinggi. Hal ini disebabkan dalam menyelesaikan masalah siswa menggunakan daya nalar. Indikasi lemahnya penalaran matematis siswa diperoleh ketika siswa diberikan masalah berikut.

\section{Contoh Masalah:}

Tentukan banyaknya penyelesaian $(x, y, z)$ yang memenuhi $5 x+y+z=21$ jika semesta pembicaraan untuk $x, y$ dan $z$ adalah anggota himpunan bilangan asli!

Salah satu contoh hasil pekerjaan siswa dalam menyelesaikan masalah tersebut adalah siswa menyatakan suatu variabel atas variabel lainnya, sehingga siswa menyimpulkan bahwa penyelesaiannya adalah $x=y=z=3$. Artinya siswa mendapatkan hasil penyelesaiannya dengan satu jawaban. Seharusnya penyelesaian masalah di atas mempunyai 30 jawaban. Hasil pekerjaan ini menunjukkan bahwa siswa menggunakan cara yang sudah mereka ketahui prosedurnya. Hal ini sesuai dengan pendapat Sa'dijah (2006) yang menyatakan bahwa pada umumnya siswa lebih suka mengerjakan soal-soal yang sudah mereka ketahui prosedur pengerjaannya atau soal-soal yang sudah "diberitahu” cara pengerjaannya melalui contoh-contoh. Secara umum siswa telah memahami apa yang diinginkan dari masalah tersebut. Akan tetapi, mereka terbiasa bekerja secara prosedural (Maimunah, 2014). 
Penalaran atau reasoning merupakan suatu proses berpikir untuk mengambil kesimpulan. Boesen, Lithner, \& Palm (2010) menyatakan bahwa "reasoning is the way of thinking, adopted to produce assertions and reach conclusions". Penalaran dapat diartikan sebagai suatu cara berpikir untuk menghasilkan suatu kesimpulan. Suriasumantri (2010) menyatakan bahwa penalaran merupakan suatu proses berpikir dalam menarik sesuatu kesimpulan berupa pengetahuan. Dalam kaitannya dengan menyelesaikan masalah, Subanji (2011) menyatakan bahwa penalaran merupakan aktivitas mental/kognitif melalui berpikir logis dan bersifat analitis. Suharnan (2005) menegaskan bahwa titik berat penalaran adalah bagaimana seseorang menarik kesimpulan dan mengevaluasi apakah kesimpulan yang dihasilkan itu valid atau tidak valid. Kesimpulan yang bersifat umum dapat ditarik dari kasus-kasus yang bersifat individual, tetapi dapat juga sebaliknya dari hal yang bersifat individual menjadi bersifat umum (Suherman \& Winataputra, 1993). Penalaran terdiri dari penalaran induktif yang disebut induksi dan penalaran deduktif yang disebut deduksi. Penalaran induktif adalah penalaran untuk menarik suatu kesimpulan dari hal-hal khusus ke hal yang umum (Sumarmo, 1987). Namun, penalaran induktif selain dapat berjalan dari khusus ke umum juga dapat berjalan dari umum ke umum. Dengan demikian, penalaran adalah aktivitas mental yang berkenaan dengan pengambilan keputusan berdasarkan informasi yang tersedia. Informasi itu dapat berbentuk verbal dan/atau visual. Informasi verbal adalah informasi yang diwujudkan dalam bentuk kata-kata atau kalimat, sedangkan informasi visual adalah informasi berupa data yang dapat diwujudkan dalam bentuk diagram, grafik, atau model. Hasil penarikan kesimpulan tersebut dapat berbentuk verbal atau visual.

Penalaran sangat diperlukan dalam pembelajaran matematika. Hudojo (2005) menyatakan bahwa mengajar sebenarnya memberi kesempatan kepada siswa untuk mencari, menanya, menebak, menalar, dan bahkan mendebat. Penalaran matematika siswa dapat dilakukan melalui pemecahan masalah atau problem solving. Langkahlangkah problem solving dikenal dengan langkah-langkah menurut Polya (1957). Pemecahan masalah menurut Wahyudin (2008) merupakan wahana untuk membangun kemampuan berpikir tingkat tinggi, karena melalui pemecahan masalah siswa harus menggunakan sejumlah keterampilan dan pengetahuan yang telah dimilikinya kemudian memadukannya untuk sampai pada suatu penyelesaian. Penalaran merupakan bagian dari 
berpikir tingkat tinggi dan elemen penting dalam pemecahan masalah (Krulik, Rudnick, \& Milou, 2003; Spector \& Park, 2012).

Yulia (2012) mengungkapkan bahwa indikator siswa telah menguasai kemampuan penalaran matematis sebagai berikut: (1) menarik kesimpulan logis, (2) memberi penjelasan menggunakan gambar, fakta, sifat, hubungan yang ada, (3) memperkirakan jawaban dan proses solusi, (4) menggunakan pola hubungan untuk menganalisis, membuat analogi, generalisasi, dan menyusun serta menguji konjektur, (5) mengajukan lawan contoh, (6) mengajukan aturan inferensi, memeriksa validitas argumen, dan menyusun argument yang valid, dan (7) menyusun pembuktian langsung, pembuktian tak langsung, dan pembuktian dengan induksi matematika.

Selain itu, indikator kemampuan penalaran yang dijelaskan dalam teknis Peraturan Dirjen Dikdasmen Depdiknas Nomor 506/C/Kep/PP/2004, diuraikan bahwa indikator siswa memiliki kemampuan penalaran adalah mampu: (1) mengajukan dugaan, (2) melakukan manipulasi matematika, (3) menarik kesimpulan, menyusun bukti, memberikan alasan atau bukti terhadap kebenaran solusi, (4) menarik kesimpulan dari pernyataan, (5) memeriksa kesahihan suatu argumen, dan (6) menemukan pola atau sifat dari gejala matematis untuk membuat generalisasi.

Pembelajaran melalui pemecahan masalah adalah proses belajar mengajar yang dilakukan dengan cara melatih murid menghadapi berbagai masalah untuk dipecahkan sendiri atau secara bersama-sama (Alipandie, 1984). Sedangkan menurut Purwanto (1999), pemecahan masalah adalah suatu proses dengan menggunakan strategi, cara, atau teknik tertentu untuk menghadapi situasi baru, agar keadaan tersebut dapat dilalui sesuai keinginan yang ditetapkan. Selain itu pengertian pemecahan masalah menurut Kisworo (2000), merupakan proses menerima masalah dan berusaha menyelesaikan masalah itu. Sedangkan Hudojo (2005) mendefinisikan pemecahan masalah sebagai usaha mencari jalan keluar dari suatu kesulitan, mencapai suatu tujuan yang tidak dengan segera dapat dicapai. Selanjutnya Polya menyatakan bahwa pemecahan masalah merupakan suatu tingkat aktivitas intelektual yang sangat tinggi. Pemecahan masalah adalah suatu aktivitas intelektual untuk mencari penyelesaian masalah yang dihadapi dengan menggunakan bekal pengetahuan yang sudah dimlliki.

Pemecahan masalah dapat juga meningkatkan kemampuan akademik siswa. Selain itu, langkah-langkah dalam pemecahan masalah sangat bermanfaat untuk menggambarkan penalaran induktif siswa (Canadas \& Castro, 2009). Pemecahan masalah 
merupakan suatu indikator bagi penyerapan konsep dan ide-ide siswa yang sedang belajar. Menurut Pedro, Navales, dan Josue (2000), salah satu aktivitas dalam pemecahan masalah yaitu: inkuiri, investigasi, dan menganalisis situasi matematis.

Dalam memecahkan masalah, setiap individu memerlukan waktu yang berbeda. Hal ini disebabkan oleh motivasi dan strategi yang digunakan dalam menyelesaikan masalah yang sedang dihadapinya. Siswono (1999) menyebutkan bahwa terdapat beberapa faktor yang mempengaruhi kemampuan pemecahan masalah, yaitu: (1) pengalaman awal, pengalaman terhadap tugas-tugas menyelesaikan soal cerita atau soal aplikasi. Pengalaman awal seperti ketakutan (pobia) terhadap matematika dapat menghambat kemampuan siswa dalam memecahkan masalah, (2) latar belakang matematika, kemampuan siswa terhadap konsep-konsep matematika yang berbeda-beda tingkatnya dapat memicu perbedaan kemampuan siswa dalam memecahkan masalah, (3) keinginan dan motivasi, dorongan yang kuat dari dalam diri (internal), seperti menumbuhkan keyakinan saya "BISA" maupun eksternal, seperti diberikan soal-soal yang menarik, menantang, kontekstual dapat mempengaruhi hasil pemecahan masalah, (4) struktur masalah, struktur masalah yang diberikan kepada siswa (pemecahan masalah), seperti format secara verbal atau gambar, kompleksitas (tingkat kesulitan soal), konteks (latar belakang cerita atau tema), bahasa soal, maupun pola masalah satu dengan masalah yang lain dapat mengganggu kemampuan siswa dalam memecahkan masalah. Siswono (1999) juga menyebutkan bahwa dalam memecahkan masalah perlu keterampilan-keterampilan yang harus dimiliki, yaitu: (1) keterampilan empiris (perhitungan, pengukuran), (2) keterampilan aplikatif untuk menghadapi situasi yang umum (seting terjadi), (3) keterampilan berpikir untuk bekerja pada suatu situasi yang tidak biasa (unfamiliar).

Polya (1957) menjelaskan empat langkah yang harus dilakukan dalam memecahkan masalah yaitu: (1) memahami masalah, merujuk pada pemahaman terhadap apa yang diketahui, apa yang ditanyakan, atau apakah syarat-syarat cukup, tidak cukup, berlebihan atau kontradiksi untuk mencari yang ditanyakan, (2) merencanakan penyelesaian, merujuk pada bagaimana strategi penyelesaian yang terkait, (3) menyelesaikan rencana penyelesaian, merujuk pada penyelesaian strategi penyelesaian yang telah disusun, dan (4) memeriksa kembali, berkaitan dengan pengecekan jawaban serta pembuatan kesimpulan akhir.

Krulik (2003) mengungkapkan tiga interpretasi umum tentang pemecahan masalah, yaitu: pemecahan masalah sebagai tujuan (goal), pemecahan masalah sebagai proses 
(process), dan pemecahan masalah sebagai keterampilan dasar (basic skill). Pemecahan masalah sebagai tujuan mengapa matematika itu diajarkan dan apa tujuan pembelajaran matematika. Dalam interpretasi ini, pemecahan masalah bebas dari masalah khusus, prosedur atau metode, dan konten matematika. Yang menjadi pertimbangan utama adalah belajar bagaimana memecahkan masalah, merupakan alasan utama untuk belajar matematika. Pemecahan masalah sebagai proses muncul dari interpretasinya sebagai proses dinamik dan terus menerus. National Council of Teachers of Mathematics (2000) mendefinisikan pemecahan masalah sebagai proses menerapkan pengetahuan yang telah diperoleh sebelumnya kedalam situasi baru dan tak dikenal. Pertimbangan utama dalam hal ini adalah metode, prosedur, strategi, dan heuristik yang siswa gunakan dalam memecahkan masalah. Sedangkan pemecahan masalah sebagai keterampilan dasar, menyangkut dua pengertian yang banyak digunakan, yaitu: keterampilan minimum yang harus dimiliki siswa dalam matematika dan keterampilan minimum yang diperlukan seseorang agar dapat menjalankan fungsinya di masyarakat.

Berdasarkan paparan di atas, maka untuk meningkatkan penalaran matematika siswa perlu dilakukan pembelajaran melalui pemecahan masalah. Menurut Ali \& Akhter (2010), pembelajaran melalui pemecahan masalah (problem solving) lebih efektif jika dibandingkan dengan pembelajaran secara tradisional. Pemecaham masalah merupakan aktivitas berpikir tingkat tinggi dan merupakan suatu usaha untuk mencari jalan keluar dari suatu kesulitan untuk mencapai tujuan. Jika siswa diberikan masalah, maka siswa harus membaca dan memahami masalah tersebut kemudian mencoba untuk membuat dugaan atas rencana penyelesaian. Selanjutnya bersama kelompok mendiskusikan pemecahan masalah, dan hasil diskusi sebagai suatu kesimpulan bersama tersebut dipresentasikan di depan kelas. Kemudian hasil diskusi kelas di evaluasi melalui tes akhir pada akhir pertemuan.

Berdasarkan hal tersebut, tujuan penelitian ini adalah untuk meningkatkan penalaran matematis siswa dengan menerapkan model pembelajaran matematika melalui pemecahan masalah. Dalam penelitian ini langkah pemecahan masalah yang digunakan adalah langkah pemecahan masalah yang dijelaskan oleh Polya (1957). Adapun aspekaspek yang harus dicantumkan siswa pada setiap langkah-langkah pemecahan masalah adalah: (1) memahami masalah, aspek yang harus dicantumkan siswa pada langkah ini meliputi apa yang diketahui dan apa yang ditanyakan, (2) merencanakan penyelesaian, aspek yang harus dicantumkan siswa pada langkah ini meliputi urutan langkah 
penyelesaian dan mengarahkan pada jawaban yang benar, (3) menyelesaikan rencana penyelesaian, aspek yang harus dicantumkan siswa pada langkah ini meliputi pelaksanaan cara yang telah dibuat dan kebenaran langkah yang sesuai dengan cara yang dibuat, (4) memeriksa kembali, aspek yang harus dicantumkan siswa pada langkah ini meliputi penyimpulan jawaban yang telah diperoleh dengan benar/memeriksa jawabannya dengan tepat.

\section{METODE PENELITIAN}

Jenis penelitian ini adalah kuasi eksperimen tanpa kelas kontrol. Dalam penelitian ini menggunakan sebuah rancangan penelitian dengan bagan pada Tabel 1. (Sugiyono, 2008).

Tabel 1.

Pre-Tes Post-Tes Design

\begin{tabular}{c|c|c}
\hline Pre-test & Perlakuan & Post-test \\
\hline $\mathrm{T}_{1}$ & $\mathrm{X}$ & $\mathrm{T}_{2}$ \\
\hline
\end{tabular}

Keterangan:

$\mathrm{T}_{1} \quad$ : nilai pre-test (sebelum diberi perlakuan)

$\mathrm{X} \quad$ : perlakuan (penerapan model pembelajaran melalui pemecahan masalah)

$\mathrm{T}_{2} \quad$ : nilai post-test (sesudah diberi perlakuan)

Penelitian ini dilakukan di SMA Al Muslimun Pelalawan Riau. Subjek penelitian yang dipilih adalah siswa kelas X-A yang berjumlah 19 orang siswa pada tahun pelajaran 2015/2016. Data dalam penelitian ini diperoleh dari guru matematika pada kelas X-A. Model pembelajaran ini dilaksanakan dalam kelompok kecil, dimana setiap kelompok beranggotakan 4-5 siswa yang terdiri dari siswa dengan kemampuan tinggi, sedang, dan rendah.

Penelitian ini terdiri dari dua tes, tes pertama yaitu pre-test yang dilakukan sebelum model pembelajaran matematika ini diterapkan dan tes kedua yaitu post-test yang dilakukan sesudah model pembelajaran matematika ini diterapkan. Penerapan model pembelajaran dalam penelitian ini melalui pemecahan masalah. Langkah-langkah pembelajaran matematika melalui pemecahan masalah adalah sebagai berikut: (1) penyajian masalah, (2) investigasi, (3) presentasi hasil, dan (4) evaluasi hasil. 
Variabel bebas dari penelitian ini adalah model pembelajaran matematika melalui pemecahan masalah. Variabel terikat dalam penelitian adalah kemampuan penalaran matematis. Bentuk data hasil pengukuran dalam penelitian ini berupa skor nilai atau angka yang diperoleh dari melakukan suatu proses berpikir untuk menghasilkan suatu kesimpulan.

Data yang diperoleh dari pengamatan dan hasil tes dianalisis untuk memaparkan keberhasilan pembelajaran setelah menerapkan model pembelajaran melalui pemecahan masalah pada materi grafik fungsi eksponen dan logaritma. Kegiatan analisis data dalam penelitian ini antara lain: (1) keterlaksanaan model pembelajaran dilakukan oleh dua orang pengamat yang telah diberikan lembar pengamatan, dan (2) analisis kemampuan penalaran matematika siswa dengan menggunakan rubrik penilaian penalaran matematis siswa. Penalaran matematis siswa dikatakan meningkat apabila nilai siswa yang mencapai penalaran matematis pada hasil post-test lebih baik dari hasil pre-test. Skor rata-rata pencapaian Penalaran Matematis (PM) siswa ditentukan berdasarkan kriteria seperti pada Tabel 2 .

Tabel 2.

Pencapaian Penalaran Matematis (PM) Siswa

\begin{tabular}{cc}
\hline Tingkat Penalaran & Kriteria \\
\hline $\mathrm{PM}<60$ & Tidak Baik (TB) \\
$60 \leq \mathrm{PM}<70$ & Kurang Baik (KB) \\
$70 \leq \mathrm{PM}<80$ & Cukup/Sedang $(\mathrm{C})$ \\
$80 \leq \mathrm{PM}<90$ & Baik (B) \\
$90 \leq \mathrm{PM} \leq 100$ & Sangat Baik (SB) \\
\hline
\end{tabular}

Lembar penilaian kemampuan pemecahan masalah ini dibuat oleh peneliti yang diadaptasi dari Mufarida (2008), dimana lembar penilaian tersebut mengacu pada empat langkah pemecahan masalah Polya. Adapun lembar penilaian kemampuan pemecahan masalah matematika siswa yang dibuat peneliti seperti pada Tabel 3.

Tabel 3.

Lembar Penilaian Kemampuan Pemecahan Masalah

\begin{tabular}{clc}
\hline \multicolumn{1}{c}{ Aspek } & \multicolumn{1}{c}{ Reaksi terhadap soal (masalah) } & Skor \\
\hline Memahami Masalah & $\begin{array}{l}\text { Tidak menuliskan/tidak menyebutkan apa yang } \\
\text { diketahui dan apa yang ditanyakan dari soal. } \\
\text { Hanya menuliskan/menyebutkan apa yang } \\
\text { diketahui. }\end{array}$ & 2 \\
\hline
\end{tabular}




\begin{tabular}{|c|c|c|}
\hline $\begin{array}{c}\text { Aspek } \\
\text { yang dinilai }\end{array}$ & Reaksi terhadap soal (masalah) & Skor \\
\hline & $\begin{array}{l}\text { Menuliskan/menyebutkan apa yang diketahui } \\
\text { dan apa yang ditanyakan dari soal dengan } \\
\text { kurang tepat. }\end{array}$ & 3 \\
\hline & $\begin{array}{l}\text { Menuliskan/menyebutkan apa yang diketahui } \\
\text { dan apa yang ditanyakan dari soal dengan tepat. }\end{array}$ & 4 \\
\hline Merencanakan & Tidak menyajikan urutan langkah penyelesaian. & 1 \\
\hline \multirow[t]{3}{*}{ Penyelesaian } & $\begin{array}{l}\text { Menyajikan urutan langkah penyelesaian, tetapi } \\
\text { urutan urutan penyelesaian yang disajikan } \\
\text { kurang tepat. }\end{array}$ & 2 \\
\hline & $\begin{array}{l}\text { Menyajikan urutan langkah penyelesaian yang } \\
\text { benar, tetapi mengarah padajawaban yang salah. }\end{array}$ & 3 \\
\hline & $\begin{array}{l}\text { Menyajikan urutan langkah penyelesaian yang } \\
\text { benar dan mengarah pada jawaban yang benar. }\end{array}$ & 4 \\
\hline Menyelesaikan Rencana & Tidak ada penyelesaian sama sekali. & 1 \\
\hline \multirow[t]{3}{*}{ Penyelesaian } & Ada penyelesaian, tetapi prosedur tidak jelas. & 2 \\
\hline & $\begin{array}{l}\text { Menggunakan prosedur tertentu yang benar, } \\
\text { tetapi jawaban salah. }\end{array}$ & 3 \\
\hline & $\begin{array}{l}\text { Menggunakan prosedur tertentu yang benar dan } \\
\text { hasil benar. }\end{array}$ & 4 \\
\hline \multirow[t]{4}{*}{ Memeriksa Kembali } & $\begin{array}{l}\text { Tidak melakukan pengecekan terhadap proses } \\
\text { dan jawaban serta tidak memberikan } \\
\text { kesimpulan. }\end{array}$ & 1 \\
\hline & $\begin{array}{l}\text { Tidak melakukan pengecekan terhadap proses } \\
\text { dan jawaban dan memberikan kesimpulan yang } \\
\text { salah. }\end{array}$ & 2 \\
\hline & $\begin{array}{l}\text { Melakukan pengecekan terhadap proses dan } \\
\text { jawaban dengan kurang tepat serta memberikan. } \\
\text { kesimpulan yang benar. }\end{array}$ & 3 \\
\hline & $\begin{array}{l}\text { Melakukan pengecekan terhadap proses dan } \\
\text { jawaban dengan tepat serta membuat kesimpulan } \\
\text { dengan benar. }\end{array}$ & 4 \\
\hline
\end{tabular}

\section{HASIL DAN PEMBAHASAN}

Pada bagian ini dipaparkan tentang penerapan model Pembelajaran Matematika melalui Pemecahan Masalah (PMPM), hasil-hasil pelaksanaan pembelajaran dengan penerapan model, dan hasil peningkatan penalaran matematis siswa. Pelaksanaan tes dalam penelitian ini dilakukan sebanyak dua kali, yaitu tes sebelum dan sesudah diberikan perlakuan berupa penerapan model Pembelajaran Matematika melalui Pemecahan Masalah (PMPM). Pelaksanaan tes pertama bertujuan untuk mengetahui penalaran matematis awal siswa (pre-test) sebelum diberikan perlakuan pada siswa, sedangkan tes kedua atau tes akhir (post-test) bertujuan mengetahui peningkatan penalaran matematis siswa setelah diberikan perlakuan. 
Penerapan model PMPM dilaksanakan dengan empat fase berikut: (1) Fase penyajian masalah meliputi: siswa secara individu memahami masalah yang terdapat dalam lembar kegiatan siswa, siswa bertanya kepada guru untuk hal-hal yang belum jelas, (2) Fase investigasi meliputi: siswa mendiskusikan penyelesaian masalah secara berkelompok, siswa bertanya kepada guru untuk hal-hal yang kurang jelas, dan siswa menyusun hasil kerja kelompok sebagai bahan presentasi, (3) Fase presentasi hasil meliputi: siswa dari salah satu kelompok mempresentasikan hasil kerjanya di depan kelas, siswa dari kelompok lain untuk memberikan tanggapan atau pertanyaan, dan siswa dari kelompok penyaji memberikan tanggapan balik, (4) Fase evaluasi hasil meliputi: siswa menarik kesimpulan dari materi yang dipelajari, dan siswa mengerjakan tes akhir pertemuan.

Hasil penelitian yang dilakukan secara kolaborasi antara peneliti dan guru matematika menunjukkan bahwa dalam proses pembelajaran matematika melalui pemecahan masalah memberikan dorongan kepada guru matematika dalam melakukan pembelajaran. Misalnya dengan memberikan kesempatan kepada siswa untuk meningkatkan daya nalarnya.

Hasil penerapan model pembelajaran matematika melalui pemecahan masalah adalah: Fase 1 (penyajian masalah), sebagian besar siswa sudah memahami masalah dan dapat mengajukan dugaan maupun ide atas masalah yang disajikan secara individu. Fase 2 (investigasi), guru telah memotivasi dan memberikan arahan kepada siswa untuk mendiskusikan kegiatan investigasi. Sebagian besar siswa sudah berdiskusi secara berkelompok, dan dapat menyusun bahan presentasi. Fase 3 (presentasi hasil), guru mempersilahkan kelompok penyaji untuk menjelaskan hasil kerja/kelompoknya. Siswa sudah terbiasanya dalam menjelaskan hasil kerjanya di depan kelas, dan penggunaan waktu telah efektif pada fase ini. Fase 4 (evaluasi), merupakan langkah yang dilakukan oleh guru untuk mengetahui sampai sejauh mana tingkat pemahaman siswa terhadap konsep-konsep yang mereka pelajari. Fase ini telah optimal, karena waktu yang tersedia telah sesuai dengan alokasi yang sudah direncanakan.

Hasil pre-test tentang tingkat pencapaian penalaran matematis siswa yang diperoleh dari tes hasil belajar dan dapat dilihat pada Tabel 4. 
Tabel 4.

Tingkat Pencapaian Penalaran Matematis (PM) Siswa pada Pre-test

\begin{tabular}{ccc}
\hline No & Tingkat Pencapaian (PM) & Jumlah Siswa \\
\hline 1 & Tidak Baik (TB) & 1 \\
2 & Kurang Baik (KB) & 8 \\
3 & Cukup/Sedang (C) & 8 \\
4 & Baik (B) & 2 \\
5 & Sangat Baik (SB) & 0 \\
\hline & Jumlah & 19 \\
\hline
\end{tabular}

Jika dirujuk pada Tabel 4, maka pencapaian penalaran matematis siswa adalah: 10,52\% dengan kriteria baik; 42,11\% siswa dengan kriteria cukup/sedang; 42,11\% siswa dengan kriteria Kuranng Baik (KB), dan 5,26\% siswa dengan kriteria Tidak Baik (TB). Hasil tersebut menunjukkan bahwa penalaran matematis siswa masih kurang optimal.

Pembelajaran menggunakan perangkat pembelajaran sebelum diterapkan model pembelajaran matematika melalui pemecahan belum memenuhi kriteria yang ditetapkan. Oleh karena itu, diadakan tindak lanjut kegiatan terhadap kegiatan pembelajaran dan perangkat pembelajaran yang digunakan. Tindak lanjutnya berupa penerapan model pembelajaran matematika melalui pemecahan masalah. Adapun hasil post-test tentang kemampuan penalaran matematika setelah diterapkannya model pembelajaran matematika melalui pemecahan masalah dapat dilihat Tabel 5.

\section{Tabel 5.}

Tingkat Pencapaian Penalaran Matematis Siswa pada Post-test

\begin{tabular}{ccc}
\hline No & Tingkat Pencapaian (PM) & Jumlah Siswa \\
\hline 1 & Tidak Baik (TB) & 0 \\
2 & Kurang Baik (KB) & 0 \\
3 & Cukup/Sedang (C) & 5 \\
4 & Baik (B) & 14 \\
5 & Sangat Baik (SB) & 0 \\
\hline & Jumlah & 19 \\
\hline
\end{tabular}

Jika dirujuk pada Tabel 5, maka penalaran matematis siswa mencapai 73,68\% siswa dengan kriteria baik (B), dan 26,32\% siswa dengan kriteria cukup/sedang (C). Secara keseluruhan hasil pada post-test penalaran matematika siswa berada pada kategori baik. Bila dilihat data hasil pre-test, hanya 52,63\% siswa berada pada kategori cukup (C) dan baik (B), sisanya 47,37\% siswa berada pada kategori tidak baik (TB) dan kurang baik (KB). Pada hasil post-test penalaran matematika siswa berada pada kategori minimal 
sedang/cukup (C). Dari data tersebut diperoleh bahwa 73,68\% siswa dengan ktiteria baik (B) dan 26,32\% siswa dengan kriteria cukup/sedang (C). Hasil tersebut menunjukkan bahwa seluruh siswa telah memiliki penalaran matematis, sehingga siswa telah memiliki kemampuan untuk mengajukan dugaan, melakukan manipulasi matematika, memberi penjelasan, dan menarik kesimpulan dengan baik.

\section{SIMPULAN DAN SARAN}

Dari hasil penelitian dengan menggunakan Model Pembelajaran Matematika melalui Pemecahan Masalah (Model PMPM) yang diterapkan dengan empat fase, yaitu: fase penyajian masalah, fase investigasi, fase presentasi hasil, dan fase evaluasi menunjukkan bahwa pelaksanaan pembelajaran dengan penerapan model PMPM memenuhi kriteria baik. Hal ini disebabkan keempat fase sebagian besar terlaksana sesuai dengan yang diharapkan. Model PMPM juga dapat meningkatkan penalaran matematis siswa kelas X-A SMA Al Muslimun Pelalawan Riau.

Beberapa saran yang dapat peneliti sampaikan pada penelitian ini adalah: (1) penerapan model pembelajaran matematika melalui pemecahan masalah perlu memperhatikan materi pembelajaran yang akan disampaikan agar model pembelajaran ini dapat berjalan secara maksimal, (2) model PMPM dapat digunakan oleh guru/peneliti matematika SMA sebagai salah satu model pembelajaran untuk meningkatkan penalaran matematis siswa kelas X-A SMA dengan memilih indikator sesuai keinginan guru/peneliti.

\section{DAFTAR RUJUKAN}

Ali, R. H. \& Akhter, A. (2010). Effect of using problem solving method in teaching mathematics on the achievement of mathematics student. Asian Social Science, 6(2), 67-72.

Alipandie, I. (1984). Didaktik metodik pendidikan umum. Surabaya: Usaha Nasional.

Armanto, D. (2002). Teaching multiplication and division realiscally in indonesian primary schools: A prototype of local instructional theory. Tesis tidak dipublikasikan. Enschede: University of Twente.

Boesen, J., Lithner, J., \& Palm T. (2010). The relation between type assessment task and the mathematical reasoning student use. Educ Stud Math, 75(1), 89-105. 
Canadas, M. C., Castro, E., \& Castro, E. (2009). Using a model to describe students' inductive reasoning in problem solving. Electronic Journal of Research in Educational Psychology, No. 17, 7(1), 261-278.

Hudojo, H. (2005). Pengembangan kurikulum dan pembelajaran matematika. Malang: UM Press.

Kisworo, A. (2000). Pembelajaran pemecahan masalah pada pembelajaran geometri di kelas I SMU Petra 5 Surabaya. Tesis tidak dipublikasikan. Surabaya: Program Pascasarjana UNESA.

Krulik, S., Rudnick, J., \& Milou, E. (2003). Teaching mathematics in the middle school. Boston: Pearson Education Inc.

Maimunah. (2014). Model pembelajaran matematika untuk meningkatkan kemampuan penalaran matematika siswa. Prosiding Seminar Nasional Pendidikan Guru Kreatif "Kunci Sukses" Pendidikan Berkemajuan, 30 November 2014. Sidoarjo: FKIP, Universitas Muhammadiyah Sidoarjo.

Mufarida, A. (2008). Kemampuan siswa dalam memecahkan masalah matematika berbentuk soal terbuka pada materi jajargenjang di kelas VII-C SMP Negeri 1 Bangsal Mojokerto. Skripsi tidak dipublikasikan. Surabaya: UNESA.

National Council of Teachers of Mathematics (NCTM). (2000). Principles and standard for school mathematics. Reston: VA Author.

Pedro, L.A.C., Navales, M.A., \& Josue, F.T. (2000). Improving analyzing of primary students using a problem solving strategy. Journal of Science and Mathematics Education in S.E. ASIA, 27(1), 33-52.

Polya, J. (1957). How to solve it: A new aspect of mathematical method. New Jersey: Princeton University Press

Purwanto, E. (1999). Strategi belajar mengajar matematika (fakta, konsep, generalisasi, dan pendekatan pemecahan masalah). Malang: FPIPS IKIP Malang.

Rochmad. (2009). Pengembangan model pembelajaran matematika beracuan konstruktivisme yang melibatkan penggunaan pola pikir induktif-deduktif (model $P M B K-I D)$ untuk siswa SMP/MTs. Disertasi tidak dipublikasikan. UNESA. Surabaya.

Sa'dijah, C. (2006). Pengembangan model pembelajaran matematika beracuan kontruktivisme untuk siswa SMP. Jurnal Math. Edu, 1(2), 109-122.

Siswono, T. Y. E. (1999). Metode pemberian tugas pengajuan soal (problem posing) dalam membelajarkan matematika pokok bahasan perbandingan di MTs Negeri 1 Surabaya. Tesis tidak dipublikasikan. Surabaya: Program Pascasarjana UNESA. 
Spector, J. M, \& Park, S. W. (2012). Argumentation, critical reasoning, and argumentation in S.B. Fee and B.R. Belland (eds.), The Role of Criticism in Understanding Problem Solving Volume 5 of The Series Explorations in the Learning Sciences, Instructional Systems and Performance, Technologies. New York: Springer.

Subanji. (2011). Teori berpikir pseudo penalaran kovariasional. Malang: UM Press.

Sugiyono. (2008). Metode penelitian kuantitatif, kualitatif, dan R\&D. Bandung: Alfabeta.

Suharnan. (2005). Psikologi kognitif (edisi revisi). Surabaya: Srikandi.

Suherman, E. \& Winataputra, U. (1993). Strategi belajar mengajar matematika. Jakarta: Depdikbud.

Sumarmo, U. (1987). Kemampuan penalaran dan pemahaman matematika siswa sma dikaitkan dengan kemampuan penalaran logik siswa dan beberapa unsur proses belajar mengajar. Disertasi tidak dipublikasikan. Bandung: Program Pascasarjana IKIP.

Suriasumantri, J. S. (2010). Filsafat ilmu. Jakarta: Pustaka Sinar Harapan.

Wahyudin. (2008). Pembelajaran dan model-model pembelajaran. Bandung: UPI Press.

Yulia. (2012). Implementasi Pembelajaran Matematika dengan Pendekatan Investigasi dalam Meningkatkan Kemampuan Penalaran Matematis Siswa SMP. Skripsi tidak dipublikasikan. Bandung: Universitas Pendidikan Indonesia (UPI). 